\title{
Maxillary fungal sinusitis secondary to extrusion of endodontic gutta percha points
}

\author{
Mark Adams, Neil Bailie
}

Department of Otolaryngology/ Head \& Neck Surgery, Royal Victoria Hospital, Belfast, UK

\section{Correspondence to} Mark Adams,

jadams08@qub.ac.uk

Accepted 19 June 2015

\section{CrossMark}

To cite: Adams M, Bailie N. BMJ Case Rep Published online: [please include Day Month Year] doi:10.1136/ bcr-2015-210193

\section{DESCRIPTION}

A 48-year-old woman was referred to otolaryngology with frontal headaches and mid-facial pain. CT scans of the paranasal sinuses revealed opacity in the left maxillary sinus suspicious for fungal sinusitis. Of note, a small linear opacity was seen in the middle of this mass (figure 1). The patient underwent a left middle meatal antrostomy, clearance of maxillary mycetoma and anterior ethmoidectomy. At the time of surgery, inspissated tan coloured concretions consistent with fungal infection were removed from the maxillary sinus. Fungal hyphae were confirmed using special stains. Identification of fungal species was not carried out in keeping with institutional policy. Two small rod-like plastic foreign bodies, measuring $8 \mathrm{~mm}$ in length and $0.5 \mathrm{~mm}$ in diameter, were embedded within the fungal ball (figure 2). On discussion with the patient after surgery, she reported previous root canal surgery to a left upper molar. She was advised to consult her dental practitioner who confirmed that two endodontic gutta percha (GP) points were missing. The affected tooth had periapical disease involving the floor of the maxillary sinus and the patient was referred to maxillofacial surgery to have this addressed.

The CT scan and clinical photograph highlight the potential overlap between dental and sinus pathology. GP points may be identified incidentally within the sinus or can present with either fungal or acute bacterial sinusitis. ${ }^{1-3}$ Maxillary sinus infection due to extrusion of GP points is likely to

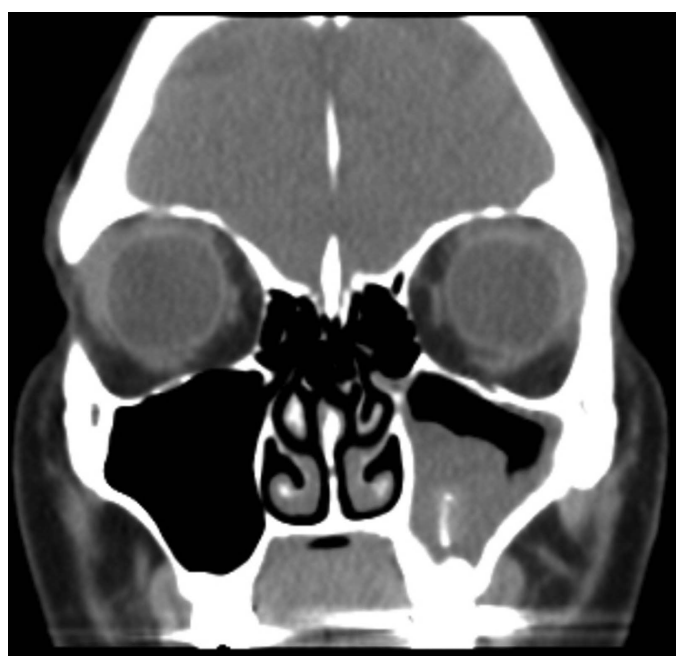

Figure 1 Multiplanar reconstructed coronal CT of paranasal sinuses showing a mass in the left maxillary sinus antrum and a small linear density within this mass.

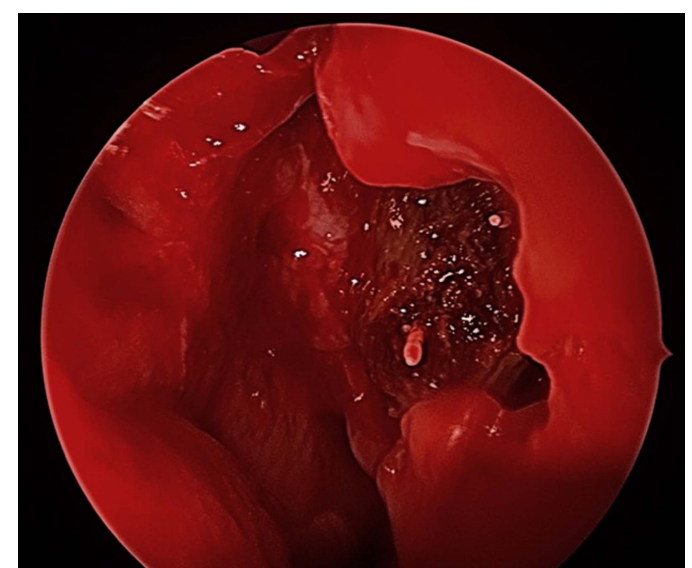

Figure 2 Intraoperative endoscopic view of the maxillary fungal mycetoma with two small plastic foreign bodies.

require surgical intervention from both an ENT (ear, nose and throat) and dental surgeon.

\section{Learning points}

- Extrusion of dental material into the maxillary sinus can give rise to disease, including fungal sinusitis.

- In such cases, the sinus disease is unlikely to be amenable to medical treatment and surgical removal of extruded endodontic material is required.

- Evidence of dental material in the maxillary sinus at surgery should prompt onward referral to a dental practitioner.

Contributors MA was involved in writing up the case and acquiring images. NB was also involved in writing up the case and provided a consultative role. Both authors were involved directly in the clinical care and follow-up of the patient.

Competing interests None declared.

Patient consent Obtained.

Provenance and peer review Not commissioned; externally peer reviewed.

\section{REFERENCES}

1 Yamaguchi K, Matsunaga T, Hayashi Y. Gross extrusion of endodontic obturation materials into the maxillary sinus: a case report. Oral Surg Oral Med Oral Pathol Oral Radiol Endod 2007;104:131-4

2 Nam M, Hong S, Park J, et al. Extrusion of gutta-percha into the nasal cavity causing maxillary fungal sinusitis: a case report. J Rhinol 2013;20:127-9.

3 Minkow B, Laufer D, Gutman D. Acute maxillary sinusitis caused by a gutta percha point. Refuat Hapeh Vehashinayim 1977;26:33-4. 


\section{Images in...}

Copyright 2015 BMJ Publishing Group. All rights reserved. For permission to reuse any of this content visit http://group.bmj.com/group/rights-licensing/permissions.

BMJ Case Report Fellows may re-use this article for personal use and teaching without any further permission.

Become a Fellow of BMJ Case Reports today and you can:

- Submit as many cases as you like

- Enjoy fast sympathetic peer review and rapid publication of accepted articles

- Access all the published articles

- Re-use any of the published material for personal use and teaching without further permission

For information on Institutional Fellowships contact consortiasales@bmjgroup.com

Visit casereports.bmj.com for more articles like this and to become a Fellow 